\title{
Selection of the Appropriate Phase Change Material for Two Innovative Compact Energy Storage Systems in Residential Buildings
}

\author{
Gabriel Zsembinszki, Angel G. Fernández ${ }^{(D)}$ and Luisa F. Cabeza * $\mathbb{D}$ \\ GREiA Research Group, Universitat de Lleida, Pere de Cabrera s/n, 25001-Lleida, Spain; \\ gabriel.zsembinszki@udl.cat (G.Z.); angel.fernandez@udl.cat (A.G.F.) \\ * Correspondence: luisaf.cabeza@udl.cat; Tel.: +34-973-003576
}

Received: 13 February 2020; Accepted: 17 March 2020; Published: 20 March 2020

Featured Application: The selection of suitable phase change material as thermal energy storage for space cooling, heating, or domestic hot water in buildings.

\begin{abstract}
The implementation of thermal energy storage systems using phase change materials to support the integration of renewable energies is a key element that allows reducing the energy consumption in buildings by increasing self-consumption and system efficiency. The selection of the most suitable phase change material is an important part of the successful implementation of the thermal energy storage system. The aim of this paper is to present the methodology used to assess the suitability of potential phase change materials to be used in two innovative energy storage systems, one of them being mainly intended to provide cooling, while the other provides heating and domestic hot water to residential buildings. The selection methodology relies on a qualitative decision matrix, which uses some common features of phase change materials to assign an overall score to each material that should allow comparing the different options. Experimental characterization of the best candidates was also performed to help in making a final decision. The results indicate some of the most suitable candidates for both systems, with RT4 being the most promising commercial phase change material for the system designed to provide cooling, while for the system designed to provide heating and domestic hot water, the most promising candidate is RT64HC, another commercial product.
\end{abstract}

Keywords: thermal energy storage (TES); phase change material (PCM); heating and cooling; material selection; selection methodology

\section{Introduction}

The use of thermal energy storage (TES) systems in applications in which either energy supply is intermittent or energy demand has large fluctuations is a key aspect of any energy system, able to reduce energy consumption or costs, besides enhancing the flexibility of the system and reducing the dependence on the energy source availability [1]. The importance of the implementation of TES systems to support the integration of renewable energies in buildings was made evident by different initiatives of the European Commission aimed at achieving a considerable reduction of energy consumption in buildings by increasing self-consumption [2].

TES technologies have been developed for applications that cover a wide temperature range, from low-temperature applications such as ice storage or the conservation and transport of temperature-sensitive materials $[3,4]$, going through medium temperature applications such as space heating and cooling in buildings [5,6], and domestic hot water (DHW) generation [7-9], up to high-temperature applications such as concentrated solar power (CSP) plants $[10,11]$. 
Among the different TES technologies available or under investigation, latent heat storage using solid-liquid phase change materials (PCM) has some advantages over sensible heat storage because it has higher heat storage capacity and a more stable thermal behavior during both charging and discharging processes. There are many studies available in the literature regarding the main aspects of the use of PCM as TES material in different applications [12-14].

Since the PCM selection procedure is an important step to achieve proper and reliable operation of the TES system, further efforts are needed to ensure that this step is done correctly. For this purpose, most studies rely on the main PCM thermophysical properties such as melting temperature, enthalpy, density, and conductivity. However, other properties such as health hazards, thermal cycling, and stability should also be taken into account to complement the most common selection criteria [15,16]. The PCM selection methodology proposed by Miró et al. [15] and Gasia et al. [16] requires a comprehensive study of different properties and aspects regarding the potential PCM candidates, which should include a detailed experimental characterization. Nevertheless, when the number of PCM candidates is quite large, a preliminary selection based on information provided by the PCM manufacturers or available in the literature is deemed necessary before conducting a more thorough experimental analysis of the most suitable PCM candidates.

The objective of this paper is to present the methodology and the results obtained for the initial step of an overall evaluation and materials selection process of the most suitable PCM to be used in two innovative systems that implement a compact hybrid electrical and thermal energy storage, intended to provide heating, cooling, and DHW in residential buildings in cold and warm weather conditions.

\section{Methodology}

\subsection{Description of the Application}

The latent heat TES investigated in this study is part of an innovative concept of two hybrid electrical and thermal energy storage systems developed and tested in the framework of HYBUILD, a research project funded by the H2020 program [17]. The main aim of the systems is to provide heating or cooling to stand-alone and district connected residential buildings by using a considerable contribution from solar energy to reduce the energy consumption of the buildings [18]. One of the concepts is mainly intended to cover the cooling demand in buildings located in Mediterranean climate regions, while the other concept is mainly designed to provide heating and DHW for buildings located in Continental climate regions. Both systems contain an electrical and thermal energy storage system to increase the use of solar energy.

In the Mediterranean concept (MED), a latent heat TES using PCM is located in the low-pressure side of a compression heat pump that is connected, by means of a DC bus, to a field of PV panels. In this way, the surplus of cold produced by the heat pump during periods of high solar radiation availability can be stored inside the TES tank, and it can be used in subsequent periods when no or insufficient solar energy is available. Since the latent heat TES is connected to both the building cooling loop and the chiller, the ideal phase change temperature of the PCM should be around $4{ }^{\circ} \mathrm{C}$ to allow a sufficient temperature difference between the PCM and the cooling water, and also an efficient charging of the PCM by the refrigerant of the chiller that evaporates inside the TES tank.

In the Continental concept (CON), the latent heat TES is located at the compressor discharge of a compression heat pump to store the sensible heat of the hot refrigerant gas before it condenses inside the condenser. Similar to the MED concept, in this case, the compression heat pump is also connected to a field of PV panels by means of a DC bus. The TES tank can be charged during both heating and cooling operation modes, and the heat stored in the PCM is used to heat the DHW up to the desired temperature. Since, in this case, the latent heat TES is used to support DHW generation, a PCM phase change temperature around $65^{\circ} \mathrm{C}$ is expected in this case. 


\subsection{PCM Selection Methodology}

The first step of the selection methodology consisted of a thorough review of potential PCM candidates available in the literature, whether commercial or not, for both MED and CON systems. Therefore, the initial search was performed focusing only on the phase change temperature of the PCM. A wider temperature range, from $0{ }^{\circ} \mathrm{C}$ to $7{ }^{\circ} \mathrm{C}$ and from $48{ }^{\circ} \mathrm{C}$ to $68^{\circ} \mathrm{C}$, was initially considered for the MED and CON systems, respectively, due to some uncertainties regarding the optimal phase change temperature at the very preliminary stage of the project development, when the PCM selection process began.

As a second step of the selection methodology, given the relatively large number of possible PCM candidates found in the first step, a pre-selection was performed in order to exclude PCMs that were not suitable either because of health hazard issues, corrosion with the tank container material (aluminum), or very bad thermophysical properties. Likewise, when two or more different PCM had similar features, only the most suitable of them was chosen.

Once a reduced group of potential PCM candidates was obtained, the third step of the methodology consisted of the development of a decision matrix as a tool to make a final selection based on objective criteria. Since there is no standard selection procedure, different selection criteria can be used, depending on the focus of the application. General properties are usually taken into account, such as phase change enthalpy, width of the phase change range, subcooling, hysteresis, thermal conductivity, density, availability, toxicity, or cost. Some of these properties were used in the pre-selection step to exclude some of the potential PCM candidates, therefore the decision matrix was built to compare the different valid options and to find the most promising ones for the two HYBUILD systems.

Hence, the following parameters were considered in the decision matrix: width of the phase change range, melting enthalpy, availability, price, and maximum working temperature in the case of the CON system. The selection of these parameters is justified by their direct impact on the system viability from the operational and economic points of view, and the relative easiness in obtaining their values. A score was assigned to each of the above decision parameters for each PCM candidate taking into account the criteria shown in Table 1.

Table 1. The scoring criteria applied to each decision parameter.

\begin{tabular}{|c|c|c|c|c|c|c|c|c|c|}
\hline \multicolumn{2}{|c|}{$\begin{array}{c}\text { Temperature Range } \\
\left(\mathrm{T}, \text { in }{ }^{\circ} \mathrm{C}\right)\end{array}$} & \multicolumn{2}{|c|}{$\begin{array}{c}\text { Enthalpy } \\
(\mathrm{h}, \text { in } \mathrm{kJ} / \mathrm{kg})\end{array}$} & \multicolumn{2}{|c|}{$\begin{array}{c}\text { Availability } \\
(-)\end{array}$} & \multicolumn{2}{|c|}{$\begin{array}{c}\text { Price } \\
(P, \text { in } € / k g)\end{array}$} & \multicolumn{2}{|c|}{$\begin{array}{c}\text { Maximum } \\
\text { Temperature } \\
\left(\mathrm{T}_{\text {max }} \text {, in }{ }^{\circ} \mathrm{C}\right)\end{array}$} \\
\hline $\mathrm{T}<2$ & 3 & $h>250$ & 3 & Yes & 3 & $\mathrm{P}<2.5$ & 3 & $\mathrm{~T}_{\max }>120$ & 3 \\
\hline $2<\mathrm{T}<3$ & 2 & $200<\mathrm{h}<250$ & 2 & No & 0 & $2.5<\mathrm{P}<5$ & 2 & $\begin{array}{c}\mathrm{T}_{\max }<120 \\
\text { or n.a. }\end{array}$ & 0 \\
\hline $3<\mathrm{T}<4$ & 1 & $150<\mathrm{h}<200$ & 1 & - & - & $5<\mathrm{P}<10$ & 1 & - & - \\
\hline $\mathrm{T}>4$ or n.a. & 0 & $h<150$ or n.a. & 0 & - & - & P $>10$ or n.a. & 0 & - & - \\
\hline
\end{tabular}

Next, a total score was calculated for each of the PCM, based on a weighted average of the partial scores obtained for each of the decision parameters. With regards to the values chosen for the weight, two scenarios were considered, as shown in Table 2: Scenario 1, in which the value of each decision parameter was selected based on authors criteria based on their experience, and Scenario 2, in which all decision parameters were given the same weight. The weighting of the parameters in Scenario 1 is the one that suits the main requirements of the systems, such as compactness and cost-effectiveness of the TES solution, which make it so PCM enthalpy and price have a higher weight with respect to the other decision parameters. 
Table 2. Reference values of the weights.

\begin{tabular}{ccccc}
\hline \multirow{2}{*}{ Decision Parameter } & \multicolumn{3}{c}{ Weight (\%) } \\
\cline { 2 - 5 } & \multicolumn{2}{c}{ MED System } & \multicolumn{2}{c}{ CON System } \\
\cline { 2 - 5 } & Scenario 1 & Scenario 2 & 20 & Scenario 1 \\
\hline Phase change range $\left(C_{\mathrm{p}}\right.$-T curve) & 25 & 25 & 25 & 20 \\
Enthalpy & 30 & 25 & 10 & 20 \\
Availability & 15 & 25 & 25 & 20 \\
Price & 30 & 25 & 20 & 20 \\
Maximum working temperature & - & - & 100 & 20 \\
Total & 100 & 100 & & 100 \\
\hline
\end{tabular}

However, a sensitivity analysis was deemed necessary to check the influence that the variation of the different weights could have on the final result. This consisted of altering the reference values (Ref) of the weights shown in Table 2 by adding or subtracting a certain amount to the reference value of two or more decision parameters. All possible combinations were considered, which satisfied the condition that the sum of the absolute values of the deviations with respect to the reference values is equal to $20 \%$. A total of 49 and 180 combinations of altered values were obtained for the MED and CON systems, respectively.

For each of the combinations obtained, the total score was calculated for all PCM candidates for both MED and CON systems, and the best three PCM of the ranking in each scenario was recorded. The average score obtained by each PCM candidate and the overall statistics for the whole set of combinations were performed to determine the significance of the results obtained using the decision matrix.

\subsection{Thermophysical Characterization}

The last step of the methodology was the analysis of the thermophysical properties of the best candidates to select the most suitable PCM for each system. The thermophysical characterization included the analysis with a differential scanning calorimeter DSC 3+ (Mettler Toledo, Schwerzenbach, Switzerland). The amount of sample used was around $10 \mathrm{mg}$ and experiments were performed under $\mathrm{N}_{2}$ flow. The PCM samples were located into $100 \mu \mathrm{L}$ cold-welded aluminum crucibles. The methodology followed to obtain the phase change temperature and enthalpy of the PCM is based on dynamic temperature programs from $20^{\circ} \mathrm{C}$ under their theoretical phase change temperatures to $20^{\circ} \mathrm{C}$ above it. The equipment precision is $\pm 0.1^{\circ} \mathrm{C}$ for temperature and $\pm 3 \mathrm{~J} / \mathrm{g}$ for enthalpy results.

Thermogravimetric analysis (TGA) was used to characterize the PCM maximum working temperature (defined as the temperature at which the material has lost $1.5 \mathrm{wt} \%$ of its mass) and the final degradation temperature. The equipment used was a TGA 2 (Mettler Toledo, Schwerzenbach, Switzerland), which allows measuring samples up to $1000{ }^{\circ} \mathrm{C}$ and has a sensitivity of $0.1 \mu \mathrm{g}$. The analyses were performed under a $50 \mathrm{~mL} / \mathrm{min} \mathrm{N}_{2}$ atmosphere. The heating rate used to perform the thermogravimetric analysis was $10^{\circ} \mathrm{C} / \mathrm{min}$ from $25^{\circ} \mathrm{C}$ to $100^{\circ} \mathrm{C}$ (low-temperature PCM) and from $25{ }^{\circ} \mathrm{C}$ to $200{ }^{\circ} \mathrm{C}$ (high-temperature PCM). Opened $100 \mu \mathrm{L}$ alumina crucibles used were filled with around $1 / 3$ volume of material leading to average sample masses of around $10 \mathrm{mg}$.

The cycling stability of the selected PCMs was characterized using a thermal cycler GeneQ BIOER TC-18/H(b) (BIOER, Hangzhou, Zhejiang, China). Due to the operating temperature range of the thermal cycler, it was only possible to cycle the pre-selected PCM for the CON system. The cycles were carried out from $20^{\circ} \mathrm{C}$ to $80^{\circ} \mathrm{C}$ using a heating rate of $12.5^{\circ} \mathrm{C} / \mathrm{min}$. Samples were taken after 10,100 , 1000, and 8000 cycles.

The chemical characterization of the PCMs before and after cycling was carried out using a Fourier transform infrared (FT-IR) spectroscopy with attenuated total reflectance (ATR), which analyses the PCM chemical degradation caused by thermal cycling. The advantage of ATR is the possibility of obtaining the spectra directly from the sample, without any specific sample preparation. The partial or total disappearance of the characteristic peaks and/or the appearance of new peaks can indicate 
that the material is being oxidized or degraded. This analysis was carried out with a PIKE MIRacle ${ }^{\mathrm{TM}}$ ATR (PIKE Technologies, Madison, WI, USA) sampling accessory with a Diamond/ZnSe ATR base, FT-IR 6300 (Hachioji, Tokyo, Japan). It allows analyzing substances in solid and liquid states. It was optimized by a wavelength range between $4000 \mathrm{~cm}^{-1}$ and $650 \mathrm{~cm}^{-1}$, and its standard spectral resolution is $4 \mathrm{~cm}^{-1}$ accounting for 64 infrared scans for each analysis; the data recorded are their means. Its functionality is based on the characteristic wave numbers at which the molecules vibrate in infrared frequencies. Since no thermal cycling tests were performed with the PCM samples for the MED system, the FT-IR analysis was only done for the PCM candidates for the CON system.

\section{Results and Discussion}

\subsection{Mediterranean System (Low Temperature)}

For the MED system, the number of potential PCM candidates found in the literature review having a phase change temperature in the range between $0^{\circ} \mathrm{C}$ and $7^{\circ} \mathrm{C}$ was around 60 . After applying some excluding criteria as explained in the methodology, this number was further reduced by half. Finally, the decision matrix was only applied to PCM with phase change temperature within the core temperature interval between $2{ }^{\circ} \mathrm{C}$ and $4{ }^{\circ} \mathrm{C}$ shown in Table 3 .

Table 3. Pre-selected available phase change material (PCM) for the Mediterranean system and some of their thermophysical properties as reported in the literature.

\begin{tabular}{|c|c|c|c|c|c|c|}
\hline $\begin{array}{c}\text { Commercial } \\
\text { Name/Composition }\end{array}$ & Type & $\begin{array}{c}\text { Melting } \\
\text { Temperature } \\
\left({ }^{\circ} \mathrm{C}\right)\end{array}$ & $\begin{array}{l}\text { Phase Change } \\
\text { Enthalpy } \\
(\mathrm{kJ} / \mathrm{kg})\end{array}$ & $\begin{array}{l}\text { Thermal } \\
\text { Conductivity } \\
(\mathrm{W} / \mathrm{m} \cdot \mathrm{K})\end{array}$ & $\begin{array}{l}\text { Density } \\
\left(\mathrm{kg} / \mathrm{m}^{3}\right)\end{array}$ & Reference \\
\hline RT3HC_1 & Organic (paraffin) & $1-3$ & 190 & $\begin{array}{l}0.20(1) \\
0.20(\mathrm{~s})\end{array}$ & $\begin{array}{l}770(1) \\
880(\mathrm{~s})\end{array}$ & [19] \\
\hline $\mathrm{A} 3$ & Organic (n.a.) & 3 & 200 & 0.210 & 765 & [20] \\
\hline 0200- Q2 BioPCM & Organic (bioPCM) & 2 & $200-230$ & $\begin{array}{c}0.2-0.7(\mathrm{l}) \\
0.25-2.5(\mathrm{~s})\end{array}$ & $\begin{array}{l}850-1300(\mathrm{l}) \\
900-1250(\mathrm{~s})\end{array}$ & [21] \\
\hline PCM-PDR03P & Organic (n.a.) & 3.5 & 185 & n.a. & 570 & {$[22]$} \\
\hline savE OM 03 & Organic (n.a.) & 3.5 & 229 & $\begin{array}{l}0.224(1) \\
0.146(1)\end{array}$ & $\begin{array}{l}835(1) \\
912(\mathrm{~s})\end{array}$ & [23] \\
\hline $\begin{array}{l}\text { Caprylic acid + lauric } \\
\text { acid }(9: 1 \text { by mol })\end{array}$ & $\begin{array}{l}\text { Organic eutectic } \\
\text { (fatty acid) }\end{array}$ & 3.8 & 151.5 & n.a. & n.a. & [24] \\
\hline RT4 & Organic (paraffin) & $2-4$ & 175 & $\begin{array}{l}0.20(1) \\
0.20(\mathrm{~s})\end{array}$ & $\begin{array}{l}770(1) \\
880(\mathrm{~s})\end{array}$ & [19] \\
\hline 0200- Q4 BioPCM & Organic (bioPCM) & 4 & $200-230$ & $\begin{array}{c}0.2-0.7(\mathrm{l}) \\
0.25-2.5(\mathrm{~s})\end{array}$ & $\begin{array}{l}850-1300(\mathrm{l}) \\
900-1250(\mathrm{~s})\end{array}$ & {$[21]$} \\
\hline PureTemp 4 & Organic (bio-based) & 4 & 195 & n.a. & n.a. & [25] \\
\hline $\begin{array}{l}\text { Tetrahydrofuran } \\
\text { clathrate hydrate }\end{array}$ & $\begin{array}{c}\text { Inorganic (clathrate } \\
\text { hydrate) }\end{array}$ & 4.4 & 255 & n.a. & n.a. & [26] \\
\hline
\end{tabular}

Figure 1 shows the results obtained by applying the decision matrix based on the scoring criteria shown in Table 1 and using the weights that correspond to Scenario 1 in Table 2. The best score was obtained by savE OM 03, a commercial product manufactured by the Indian company PLUSS ${ }^{\circledR}$ [23]. The second-best score was obtained by another commercial PCM, RT4, manufactured by the German company Rubitherm [19]. Three other commercial PCM, RT3HC_1 [19], A3 [20], and PureTemp 4 [25], share the third place of the ranking with very similar scores.

Furthermore, three of the pre-selected PCM candidates among those that obtained the highest score were characterized in the laboratory. Figure 2 shows the results of the DSC analysis of savE OM 03, RT4, and RT3HC_1 pre-selected PCM candidates. 


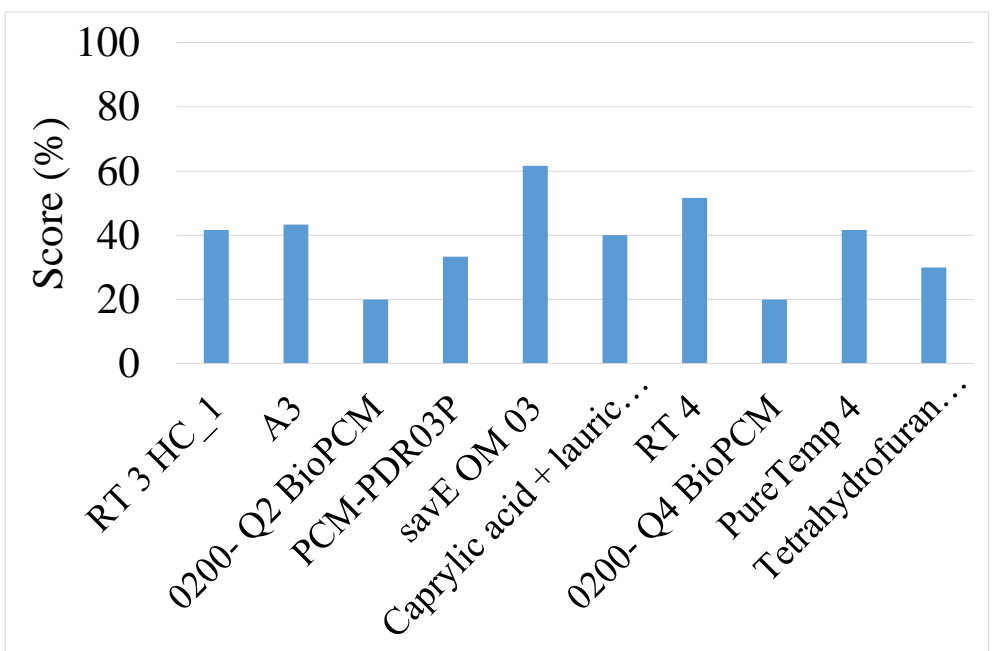

Figure 1. Score obtained by each of the pre-selected PCM candidates in Scenario 1 for the Mediterranean concept (MED) system.

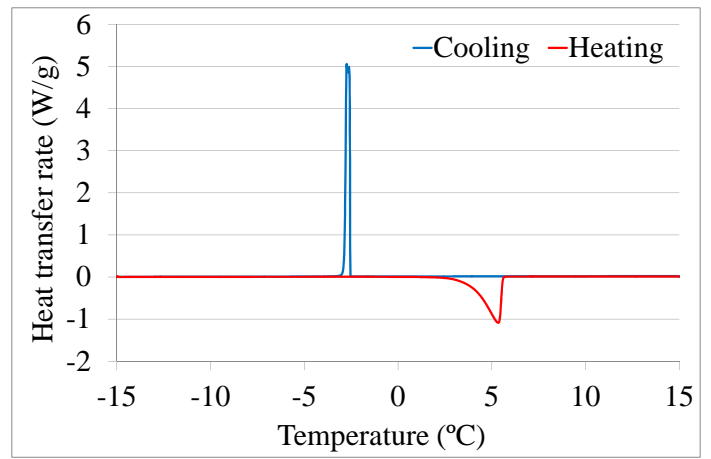

(a)

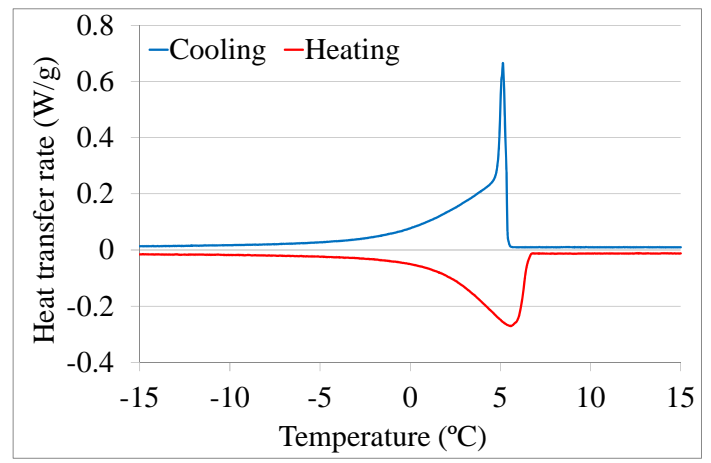

(b)

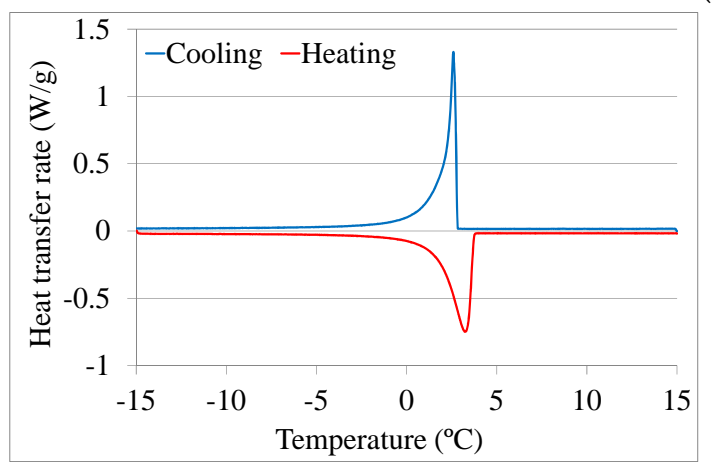

(c)

Figure 2. DSC analysis of three of the most promising pre-selected PCM for the MED system. (a) savE OM 03; (b) RT4; (c) RT3HC_1.

On the one hand, it can be seen that both PCM from Rubitherm have an acceptable behavior in both heating and cooling processes, with the temperature difference between the heating and cooling peaks being around $0.5{ }^{\circ} \mathrm{C}$. Moreover, RT3HC_1 shows a sharper curve profile around the phase change temperature and a slightly higher phase change enthalpy than RT4. On the other hand, savE OM 03 has a heating curve more similar to the one for RT3HC_1, while the cooling curve is by far much sharper than the ones for the two PCM from Rubitherm. However, the difference between the heating and cooling peaks corresponding to melting and solidification curves for savE OM 03 is about $8{ }^{\circ} \mathrm{C}$, which is a serious drawback for the implementation of this PCM in practical applications. 
The results of the TGA performed for the same three PCM candidates for the MED system are shown in Figure 3. The mass loss of the three PCM is less than $0.1 \%$ when the temperature is below $48^{\circ} \mathrm{C}$ and only RT3HC_1 reaches a mass loss of $1.5 \mathrm{wt} \%$ at $87^{\circ} \mathrm{C}$. At $100{ }^{\circ} \mathrm{C}$. The mass losses for savE OM 03, RT4, and RT3HC_1 are $0.45 \mathrm{wt} \%, 0.91 \mathrm{wt} \%$, and $2.15 \mathrm{wt} \%$, respectively. If a lower heating rate of e.g., $1{ }^{\circ} \mathrm{C} / \mathrm{min}$ was used instead of $10^{\circ} \mathrm{C} / \mathrm{min}$, the temperature for the stability limit would be lower than the values shown here, but still, the mass loss in the temperature range of the application would be negligible. Therefore, from this point of view, the three PCM candidates are suitable because the ambient temperature is expected to be below $50{ }^{\circ} \mathrm{C}$ in practically all locations in the world.

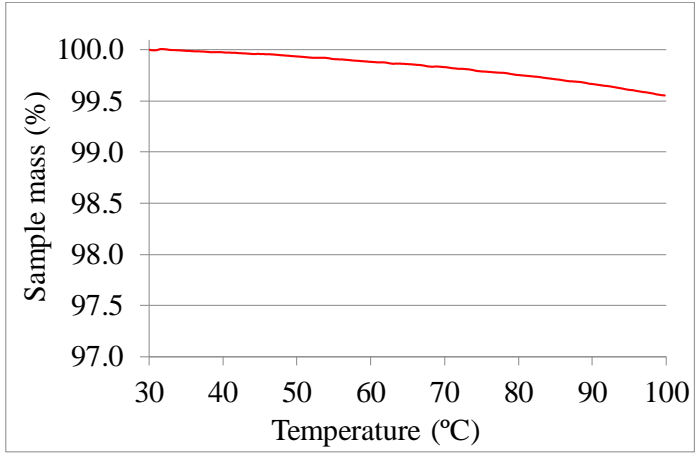

(a)

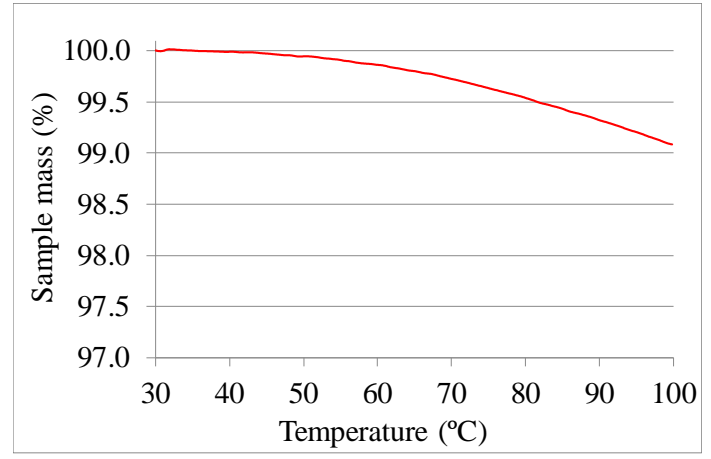

(b)

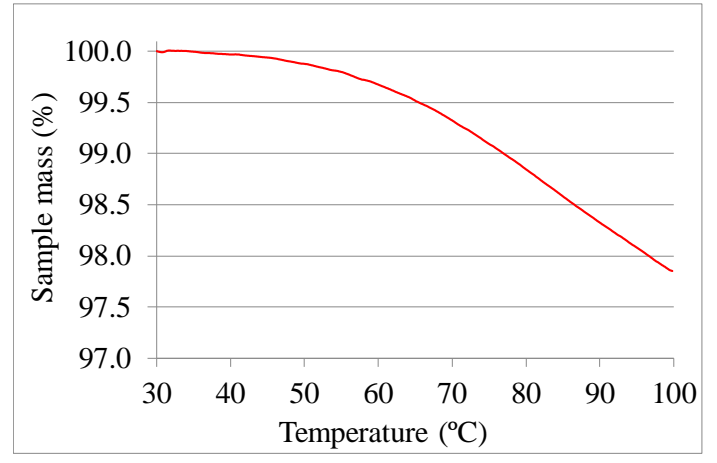

(c)

Figure 3. TGA of the PCM candidates for the MED system. (a) savE OM 03; (b) RT4; (c) RT3HC_1.

To summarize, the results given by the decision matrix indicate that savE OM 03, RT4, A3, RT3HC_1, and PureTemp 4 are the most promising options. Nevertheless, because of the very large hysteresis of around $8{ }^{\circ} \mathrm{C}$, savE OM 03 is not a recommended option for the MED solution.

\subsection{Continental System}

As a result of the literature review, more than 120 PCM potential candidates were initially found for the CON system, which doubles the number found for the MED system. After the pre-selection procedure, the number of candidates was considerably reduced, so that only $25 \mathrm{PCM}$ were taken into consideration in the decision matrix. The list of all pre-selected PCM candidates for the Continental system is shown in Table 4. 
Table 4. Pre-selected PCM for the Continental system and some of their thermophysical properties as reported in the literature.

\begin{tabular}{|c|c|c|c|c|c|c|}
\hline $\begin{array}{c}\text { Commercial } \\
\text { Name/Composition }\end{array}$ & Type & $\begin{array}{c}\text { Melting } \\
\text { Temperature } \\
\left({ }^{\circ} \mathrm{C} .\right)\end{array}$ & $\begin{array}{l}\text { Phase Change } \\
\text { Enthalpy } \\
\text { (kJ/kg) }\end{array}$ & $\begin{array}{c}\text { Thermal } \\
\text { Conductivity } \\
(\mathrm{W} / \mathrm{m} \cdot \mathrm{K})\end{array}$ & $\begin{array}{l}\text { Density } \\
\left(\mathrm{kg} / \mathrm{m}^{3}\right)\end{array}$ & Reference \\
\hline A50 & Organic (n.a.) & 50 & 218 & 0.18 & 810 & [20] \\
\hline 0500- Q50 BioPCM & Organic (bioPCM) & 50 & $200-230$ & $\begin{array}{c}0.2-0.7(\mathrm{l}) \\
0.25-2.5(\mathrm{~s})\end{array}$ & $\begin{array}{l}850-1300(\mathrm{l}) \\
900-1250(\mathrm{~s})\end{array}$ & [21] \\
\hline savE OM50 & $\begin{array}{l}\text { Organic (fatty acids } \\
\text { mixture) }\end{array}$ & $50-51$ & 223 & $\begin{array}{l}0.14(\mathrm{l}) \\
0.21(\mathrm{~s})\end{array}$ & $\begin{array}{l}859(\mathrm{l}) \\
961(\mathrm{~s})\end{array}$ & [23] \\
\hline RT54HC & Organic (paraffin) & $53-54$ & 200 & 0.2 & $\begin{array}{l}800(1) \\
850(\mathrm{~s})\end{array}$ & [19] \\
\hline $\begin{array}{c}\text { Stearic acid } \\
\left(\mathrm{CH}_{3}\left(\mathrm{CH}_{2}\right)_{16}-\mathrm{COOH}\right)\end{array}$ & Organic (fatty acid) & 54 & 157 & $\begin{array}{l}0.17(\mathrm{l}) \\
0.29(\mathrm{~s})\end{array}$ & $940(\mathrm{~s})$ & [27] \\
\hline Cetyl stearate & Organic (ester) & 54.6 & $212.1-216.3$ & n.a. & n.a. & [26] \\
\hline savE OM 55 & $\begin{array}{l}\text { Organic (mixture of } \\
\text { fatty acids) }\end{array}$ & 55 & 208 & $\begin{array}{l}0.16(\mathrm{l}) \\
0.1(\mathrm{~s})\end{array}$ & $\begin{array}{l}841(\mathrm{l}) \\
935(\mathrm{~s})\end{array}$ & [23] \\
\hline 0500- Q56 BioPCM & Organic (bioPCM) & 56 & $200-230$ & $\begin{array}{c}0.2-0.7(\mathrm{l}) \\
0.25-2.5(\mathrm{~s})\end{array}$ & $\begin{array}{l}850-1300(\mathrm{l}) \\
900-1250(\mathrm{~s})\end{array}$ & [21] \\
\hline $\begin{array}{c}\text { Tristearin } \\
\left(\left(\mathrm{C}_{17} \mathrm{H}_{35} \mathrm{COO}\right)_{3} \mathrm{C}_{3} \mathrm{H}_{5}\right)\end{array}$ & Organic & 56 & 190.8 & n.a. & $862(1)$ & [26] \\
\hline PureTemp 58 & Organic (bio-based) & 58 & 225 & $\begin{array}{l}0.15(\mathrm{l}) \\
0.25(\mathrm{~s})\end{array}$ & $\begin{array}{l}810(\mathrm{l}) \\
890(\mathrm{~s})\end{array}$ & [25] \\
\hline $\mathrm{A} 58 \mathrm{H}$ & Organic (n.a.) & 58 & 243 & 0.18 & 820 & [20] \\
\hline $\begin{array}{c}66.7 \% \text { Polyethylene oxide } \\
10000+33.3 \% \text { Myristic } \\
\text { acid }\end{array}$ & $\begin{array}{l}\text { Organic (plastic }+ \\
\text { fatty acid) }\end{array}$ & 58.7 & 191 & n.a. & n.a. & [28] \\
\hline \multirow[t]{3}{*}{ Climsel C58 } & $\begin{array}{l}\text { Inorganic (salt } \\
\text { hydrate) }\end{array}$ & 58 & 259 & 1.46 & n.a. & {$[12,14]$} \\
\hline & & $55-58$ & 260 & $\begin{array}{l}0.47(\mathrm{l}) \\
0.57(\mathrm{~s})\end{array}$ & 1400 & [29] \\
\hline & & 58 & 80 & $0.5-0.7$ & 1460 & {$[30]$} \\
\hline THP 5860 & Organic (paraffin) & $55-60$ & 153 & n.a. & n.a. & $\begin{array}{c}\text { Own } \\
\text { measurements }\end{array}$ \\
\hline Paraffin C27 & Organic (paraffin) & 58.8 & 236 & n.a. & n.a. & [31] \\
\hline RT60 & Organic (paraffin) & $58-60$ & 214 & 0.2 & n.a. & [30] \\
\hline Stearyl stearate & Organic (ester) & 59.2 & $214.75-214.93$ & n.a. & n.a. & [26] \\
\hline PureTemp 63 & Organic (bio-based) & 63 & 206 & $\begin{array}{l}0.15(\mathrm{l}) \\
0.25(\mathrm{~s})\end{array}$ & $\begin{array}{l}840(1) \\
920(\mathrm{~s})\end{array}$ & {$[25]$} \\
\hline RT64HC & Organic (n.a.) & $63-65$ & 250 & 0.2 & $\begin{array}{l}780(1) \\
880(\mathrm{~s})\end{array}$ & [19] \\
\hline $\begin{array}{c}\text { Stearyl arachidate } \\
\left(\mathrm{C}_{38} \mathrm{H}_{76} \mathrm{O}_{2}\right)\end{array}$ & Organic (ester) & 64.96 & 226 & n.a. & $\begin{array}{l}2350(\mathrm{l}) \\
1930(\mathrm{~s})\end{array}$ & [26] \\
\hline $\begin{array}{c}50 \% \mathrm{CH}_{3} \mathrm{CONH}_{2}+50 \% \\
\mathrm{C}_{17} \mathrm{H}_{35} \mathrm{COOH}\end{array}$ & Organic (eutectic) & 65 & 218 & n.a. & n.a. & [31] \\
\hline 0500- Q65 BioPCM & Organic (bioPCM) & 65 & $200-230$ & $\begin{array}{c}0.2-0.7(\mathrm{l}) \\
0.25-2.5(\mathrm{~s})\end{array}$ & $\begin{array}{l}850-1300(\mathrm{l}) \\
900-1250(\mathrm{~s})\end{array}$ & [21] \\
\hline savE FS 65 & $\begin{array}{l}\text { Organic (blend of } \\
\text { organic material in } \\
\text { polymer matrix) }\end{array}$ & $66-68$ & 218 & $0.25(\mathrm{~s})$ & $842(\mathrm{~s})$ & [23] \\
\hline PureTemp 68 & Organic (bio-based) & 68 & 213 & $\begin{array}{l}0.15(\mathrm{l}) \\
0.25(\mathrm{~s})\end{array}$ & $\begin{array}{l}870(1) \\
960(\mathrm{~s})\end{array}$ & [25] \\
\hline 0500- Q68 BioPCM & Organic (bioPCM) & 68 & $200-235$ & $\begin{array}{c}0.2-0.7(\mathrm{l}) \\
0.25-2.5(\mathrm{~s})\end{array}$ & $\begin{array}{l}850-1300(\mathrm{l}) \\
900-1250(\mathrm{~s})\end{array}$ & [21] \\
\hline
\end{tabular}

Figure 4 shows the results obtained after applying the decision matrix based on the scoring criteria shown in Table 1 and using the weights that correspond to Scenario 1 in Table 2 only to pre-selected $\mathrm{PCM}$ with a phase change temperature between $60^{\circ} \mathrm{C}$ and $65^{\circ} \mathrm{C}$, which seems to be the most suitable for the HYBUILD CON concept.

In this temperature range, the commercial product RT64HC manufactured by Rubitherm [19] obtained the best score, followed by the bio-based PureTemp 63 commercial PCM manufactured by the American company Entropy Solution LLC [25]. The third position in the ranking is occupied by another commercial PCM, TH5860, manufactured by German company Terr Hel [32]. The same as for the MED system, shipment costs and other potential additional costs should also be taken into account if a final decision should be made in a specific case, which might affect the ultimate choice for the PCM to be used. 


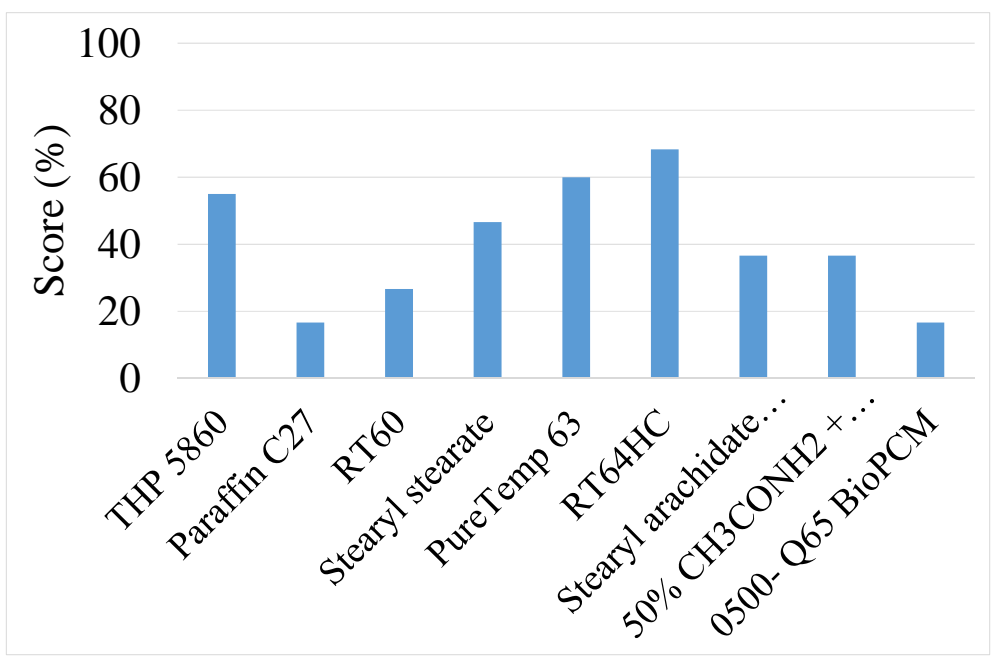

Figure 4. Score obtained by each of the pre-selected PCM candidates in Scenario 1 for the CON system.

The best three PCM candidates, i.e., RT64HC, PureTemp63, and TH5860, were characterized in the laboratory. Figure 5 shows the results of the DSC analysis of different samples after $0,10,100,1000$, and 8000 cycles. Both RT64HC and TH5860 show fairly good stability even after 8000 cycles, while PureTemp63 shows an increase in the hysteresis from $3{ }^{\circ} \mathrm{C}$ to $6{ }^{\circ} \mathrm{C}$ after only 100 cycles. From this point of view, RT64HC and TH5860 are suitable options for this application.

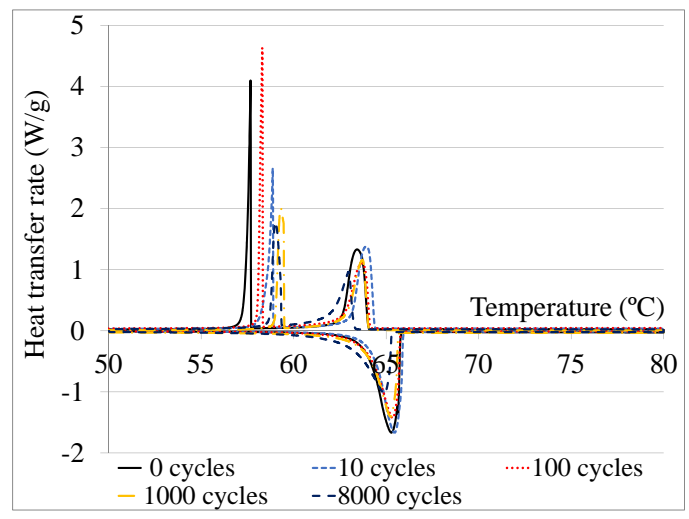

(a)

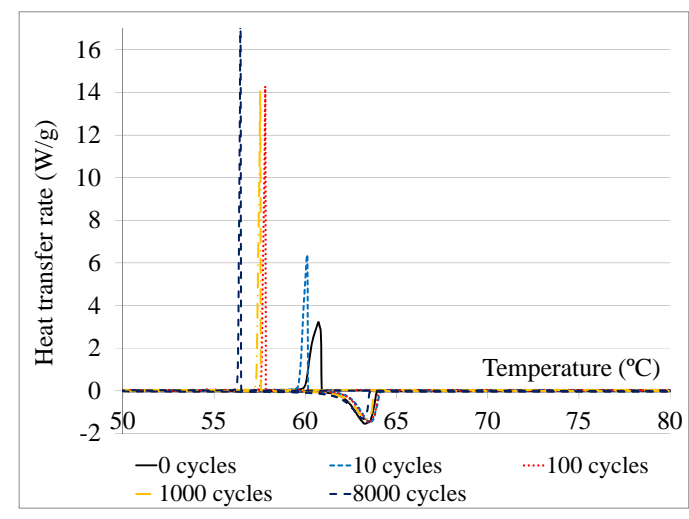

(b)

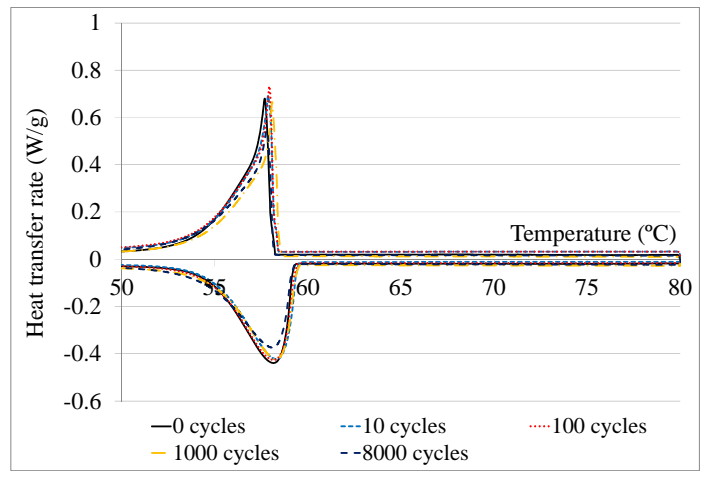

(c)

Figure 5. DSC analysis of the cycled PCM. (a) RT64HC; (b) PureTemp 63; (c) THP5860. 
The results of the FT-IR analysis performed with the same cycled PCM are shown in Figure 6. No significant changes can be observed in the three PCM as a consequence of the thermal cycling, especially for THP5860, whose spectral curves are practically the same for all cycle numbers.

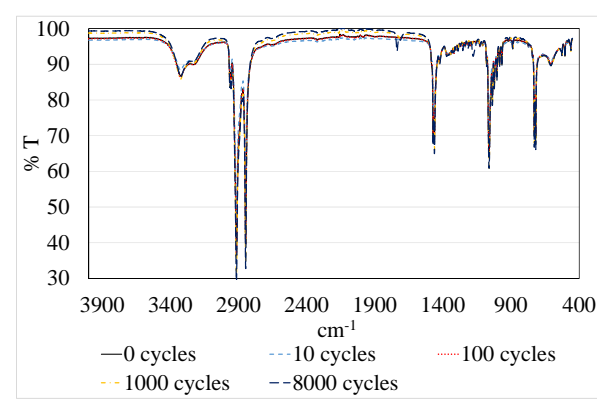

(a)

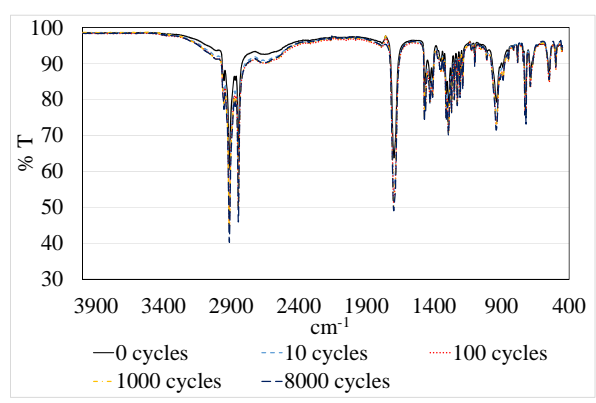

(b)

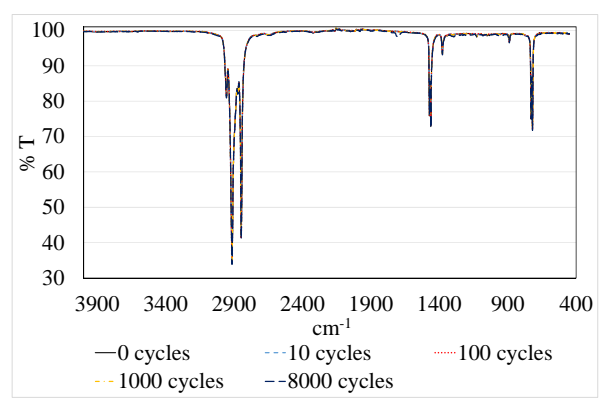

(c)

Figure 6. FT-IR analysis of the cycled PCM. (a) RT64HC; (b) PureTemp 63; (c) THP5860.

The results of the TGA analysis of the same PCM candidates as above are shown in Figure 7.

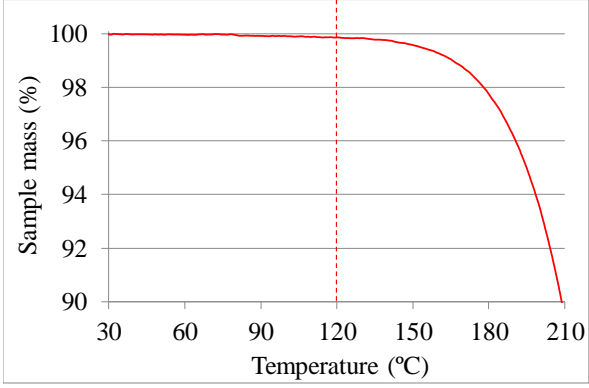

(a)

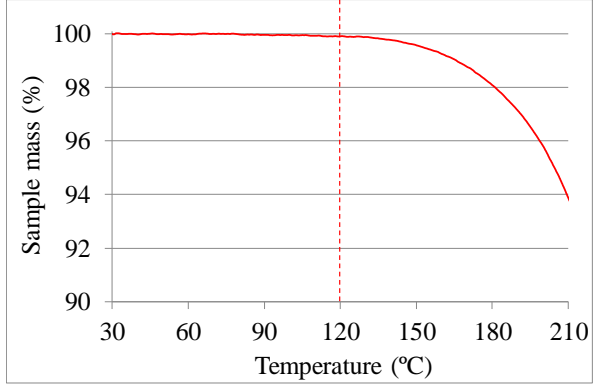

(b)

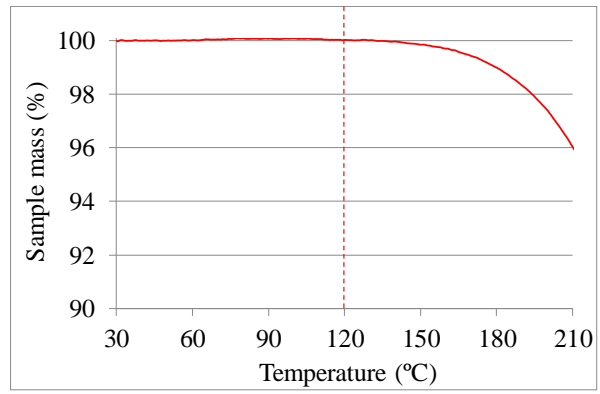

(c)

Figure 7. TGA analysis of the cycled PCM. (a) RT64HC; (b) PureTemp 63; (c) THP5860. 
The mass loss of RT64HC and PureTemp 63 at $120{ }^{\circ} \mathrm{C}$ are $0.13 \%$ and $0.09 \%$, respectively, while THP5860 does not lose weight until the temperature reaches around $135^{\circ} \mathrm{C}$. The temperatures at which the mass loss reaches $1.5 \mathrm{wt} \%$ are $173{ }^{\circ} \mathrm{C}, 174{ }^{\circ} \mathrm{C}$, and $188^{\circ} \mathrm{C}$ for RT64HC, PureTemp 63 , and THP5860, respectively. If a lower heating rate of e.g., $1{ }^{\circ} \mathrm{C} / \mathrm{min}$ was used instead of $10^{\circ} \mathrm{C} / \mathrm{min}$, the temperature for the stability limit would be lower than the values shown here, but still, the mass loss in the temperature range of the application would be negligible.

In summary, according to the decision matrix, the most promising PCM for the CON system, with a phase change temperature between $60^{\circ} \mathrm{C}$ and $65^{\circ} \mathrm{C}$, are RT64HC, PureTemp 63, and THP5860. Furthermore, the results obtained by DSC, FT-IR, and TGA confirm that RT64HC and THP5860 are adequate from this point of view, while PureTemp 63 is not indicated because it failed the cycling tests.

\subsection{Sensitivity Analysis of the Selection Criteria}

The results of the sensitivity analysis are shown in Tables 5 and 6 for the MED and CON systems, respectively, for both scenarios considered as explained in Section 2.2. The average values of the total score are shown in both tables along with the standard deviation calculated over the whole set of altered values of the weights.

Table 5. Average score obtained by the PCM candidates for the MED system.

\begin{tabular}{|c|c|c|c|c|c|c|}
\hline \multirow[b]{2}{*}{ No. } & \multicolumn{3}{|c|}{ Scenario 1} & \multicolumn{3}{|c|}{ Scenario 2} \\
\hline & $\begin{array}{c}\text { Commercial } \\
\text { Name/Composition }\end{array}$ & $\begin{array}{l}\text { Average } \\
\text { Score } \\
(\%)\end{array}$ & $\begin{array}{c}\text { Standard } \\
\text { Deviation } \\
(\%)\end{array}$ & $\begin{array}{c}\text { Commercial } \\
\text { Name/Composition }\end{array}$ & $\begin{array}{c}\text { Average } \\
\text { Score } \\
(\%)\end{array}$ & $\begin{array}{c}\text { Standard } \\
\text { Deviation } \\
(\%)\end{array}$ \\
\hline 1 & savE OM 03 & 61.7 & 4.6 & savE OM 03 & 66.7 & 4.6 \\
\hline 2 & RT4 & 51.7 & 5.4 & RT4 & 58.4 & 5.4 \\
\hline 3 & $\mathrm{~A} 3$ & 43.3 & 7.2 & $\begin{array}{l}\text { Caprylic acid + lauric acid (9:1 } \\
\text { by mol) }\end{array}$ & 50.2 & 9.6 \\
\hline 4 & RT3HC_1 & 41.7 & 7.2 & RT3HC_1 & 50.1 & 7.2 \\
\hline 5 & PureTemp 4 & 41.7 & 7.2 & PureTemp 4 & 50.1 & 7.2 \\
\hline 6 & $\begin{array}{c}\text { Caprylic acid + lauric acid (9:1 by } \\
\text { mol) }\end{array}$ & 40.2 & 9.6 & $\mathrm{~A} 3$ & 49.9 & 7.2 \\
\hline 7 & PCM-PDR03P & 33.3 & 7.1 & PCM-PDR03P & 41.6 & 7.1 \\
\hline 8 & $\begin{array}{l}\text { Tetrahydrofuran clathrate } \\
\text { hydrate }\end{array}$ & 29.9 & 8.4 & $\begin{array}{c}\text { Tetrahydrofuran clathrate } \\
\text { hydrate }\end{array}$ & 24.9 & 8.4 \\
\hline 9 & 0200- Q2 BioPCM & 19.9 & 5.6 & 0200- Q2 BioPCM & 16.6 & 5.6 \\
\hline 10 & 0200- Q4 BioPCM & 19.9 & 5.6 & 0200- Q4 BioPCM & 16.6 & 5.6 \\
\hline
\end{tabular}

Table 6. Average values obtained by the PCM candidates for the CON system.

\begin{tabular}{|c|c|c|c|c|c|c|}
\hline \multirow[b]{2}{*}{ No. } & \multicolumn{3}{|c|}{ Scenario 1} & \multicolumn{3}{|c|}{ Scenario 2} \\
\hline & Commercial Name/Composition & $\begin{array}{c}\text { Average } \\
\text { Score } \\
(\%)\end{array}$ & $\begin{array}{c}\text { Standard } \\
\text { Deviation } \\
(\%)\end{array}$ & $\begin{array}{c}\text { Commercial } \\
\text { Name/Composition }\end{array}$ & $\begin{array}{c}\text { Average } \\
\text { Score } \\
(\%)\end{array}$ & $\begin{array}{c}\text { Standard } \\
\text { Deviation } \\
(\%)\end{array}$ \\
\hline 1 & RT64HC & 68.4 & 7.2 & RT64HC & 73.3 & 7.2 \\
\hline 2 & PureTemp 63 & 60.1 & 6.7 & PureTemp 63 & 66.7 & 6.8 \\
\hline 3 & THP 5860 & 55.1 & 7.2 & THP 5860 & 60.0 & 7.2 \\
\hline 4 & Stearyl stearate & 46.8 & 8.3 & Stearyl stearate & 53.3 & 8.4 \\
\hline 5 & Stearyl arachidate $(\mathrm{C} 38 \mathrm{H} 76 \mathrm{O} 2)$ & 36.6 & 7.8 & Stearyl arachidate $(\mathrm{C} 38 \mathrm{H} 76 \mathrm{O} 2)$ & 33.3 & 7.9 \\
\hline 6 & $\begin{array}{c}50 \% \mathrm{CH} 3 \mathrm{CONH} 2+50 \% \mathrm{C} 17 \mathrm{H} 35 \\
\mathrm{COOH}\end{array}$ & 36.6 & 7.8 & $\begin{array}{c}50 \% \mathrm{CH} 3 \mathrm{CONH} 2+50 \% \mathrm{C} 17 \mathrm{H} 35 \\
\mathrm{COOH}\end{array}$ & 33.3 & 7.9 \\
\hline 7 & RT60 & 26.8 & 6.6 & RT60 & 33.3 & 6.8 \\
\hline 8 & Paraffin C27 & 16.6 & 5.0 & Paraffin C27 & 13.3 & 5.0 \\
\hline 9 & 0500- Q65 BioPCM & 16.6 & 5.0 & 0500- Q65 BioPCM & 13.3 & 5.0 \\
\hline
\end{tabular}

Table 5 shows that, according to the average score obtained for all possible combinations, the first and the second-best options are savE OM 03 and RT4, respectively, in both Scenarios 1 and 2. The third place is occupied by A3 in scenario1 and by the mixture caprylic acid + lauric acid (9:1 by mol) in Scenario 2.

For the CON case, the first place is occupied by RT64HC, followed by PureTemp 63 in the second place, and by THP 5860 in the third place in both Scenarios 1 and 2.

The frequency distributions with respect to the places occupied by the best candidates over the whole set of altered values of the weights are shown in Tables 7 and 8, for the MED and CON systems, 
respectively. As seen in Table 7, savE OM 03 is always the first option in both scenarios, while RT4 is the second-best option in the vast majority of cases in both scenarios. Therefore, it can be concluded that the sensitivity analysis confirms that the results obtained using the decision matrix of the MED concept are reliable and they are practically not affected by reasonably small variations in the weights of the decision parameters.

Table 7. Ranking of the best three PCM candidates and frequency distribution for the MED system.

\begin{tabular}{ccccc}
\hline \multirow{2}{*}{ Position } & \multicolumn{2}{c}{ Scenario 1 } & \multicolumn{2}{c}{ Scenario 2 } \\
\cline { 2 - 5 } & $\begin{array}{c}\text { Commercial } \\
\text { Name/Composition }\end{array}$ & Frequency & $\begin{array}{c}\text { Commercial } \\
\text { Name/Composition }\end{array}$ & Frequency \\
\hline 1st & savE OM 03 & $49 / 49(100 \%)$ & savE OM 03 & $49 / 49(100 \%)$ \\
2nd & RT4 & $47 / 49(95.9 \%)$ & RT4 & $45 / 49(91.8 \%)$ \\
3rd & A3 & $23 / 49(46.9 \%)$ & Caprylic acid + lauric acid & (9:1 by mol) \\
& & & & $28 / 49(57.1 \%)$ \\
\hline
\end{tabular}

Table 8. Ranking of the best three PCM candidates and frequency distribution for the CON system.

\begin{tabular}{ccccc}
\hline \multirow{2}{*}{ Position } & \multicolumn{2}{c}{ Scenario 1 } & \multicolumn{2}{c}{ Scenario 2 } \\
\cline { 2 - 5 } & $\begin{array}{c}\text { Commercial } \\
\text { Name/Composition }\end{array}$ & Frequency & $\begin{array}{c}\text { Commercial } \\
\text { Name/Composition }\end{array}$ & Frequency \\
\hline 1st & RT64HC & $172 / 180(95.6 \%)$ & RT64HC & $172 / 180(95.6 \%)$ \\
2nd & PureTemp 63 & $135 / 180(75.0 \%)$ & PureTemp 63 & $150 / 180(83.3 \%)$ \\
3rd & THP5860 & $109 / 180(60.6 \%)$ & THP5860 & $111 / 180(61.7 \%)$ \\
\hline
\end{tabular}

Table 8 shows that for the CON system RT64HC is the first option in the vast majority of cases (95.6\%) in both scenarios, while PureTemp 63 is the second-best option in $75 \%$ of the cases in Scenario 1 , and in $83.3 \%$ in Scenario 2. This means that, except for very few cases that correspond to specific combinations of values for the weights of the decision parameters, which deviate from the reference values considered by the authors, the selection of RT64HC as the best option for the CON concept is quite robust and justified.

\section{Conclusions}

This paper presented the methodology applied as the initial step of an overall evaluation and materials selection process of the most suitable PCM to be implemented as TES in two innovative compact systems aimed to provide heating, cooling, and domestic hot water (DHW) in residential buildings in the Mediterranean and Continental regions in a more efficient way.

A qualitative decision matrix was used in the pre-screening process to assess the potential of the most promising PCM candidates, by assigning a score to a few relevant properties and calculating a total score based on a weighted average of the scores obtained by the single properties of each PCM. The melting enthalpy and temperature range, availability, cost, and maximum allowed working temperature (for the CON concept), were considered as relevant properties in the decision matrix. A sensitivity analysis was also performed to check the robustness of the selection matrix and the influence that variations in the values assigned to the different weights might have on the results.

For the MED system, which requires a PCM with phase change temperature around $4{ }^{\circ} \mathrm{C}$, given the initial information available, RT4, A3, RT3HC_1, and PureTemp 4 were the most promising options out of a total of ten PCM candidates assessed using the decision matrix. A detailed experimental characterization based on DSC and TGA analysis showed that save OM 03 was unacceptable.

Regarding the CON system, for which the desired phase change temperature should be between $60{ }^{\circ} \mathrm{C}$ and $65^{\circ} \mathrm{C}$, given the initial information available, RT64HC, PureTemp 63, and THP5860 were the most promising PCM candidates out of a total of nine PCM assessed using the decision matrix. The detailed experimental characterization based on DSC, thermal cycling, and TGA analysis confirmed that these PCMs were suitable options for the CON system. 
It is also important to highlight that the selection process described in this study should be viewed as an initial step in an overall evaluation/materials selection process for the described applications. Since transportation costs and any other potential additional costs were not taken into consideration in the decision matrix, the results presented here could be different, although they can still serve as the basis for deeper analysis for any specific location and characteristics of the building where either the MED or the CON HYBUILD solution is intended to be implemented. Moreover, a further assessment of the actual thermophysical evaluation of the attained materials, as well as investigating the transient performance of the system and the role of the material selected are crucial steps to ensure the good performance of the entire system.

Author Contributions: Conceptualization, G.Z. and L.F.C.; methodology, G.Z. and A.G.F.; lab testing, A.G.F.; software, G.Z.; formal analysis, G.Z., A.G.F., and L.F.C.; investigation, G.Z., and L.F.C.; writing-original draft preparation, G.Z. and A.G.F.; writing-review and editing, L.F.C.; supervision, L.F.C.; project administration, L.F.C.; funding acquisition, L.F.C. All authors have read and agreed to the published version of the manuscript.

Funding: This project has received funding from the European Union's Horizon 2020 research and innovation programme under grant agreement No 768824 (HYBUILD). This work was partially funded by the Ministerio de Ciencia, Innovación y Universidades de España (RTI2018-093849-B-C31 - MCIU/AEI/FEDER, UE). This work was partially funded by the Ministerio de Ciencia, Innovación y Universidades - Agencia Estatal de Investigación (AEI) (RED2018-102431-T). This work is partially supported by ICREA under the ICREA Academia programme. The authors would like to thank the Catalan Government for the quality accreditation given to their research group (GREiA 2017 SGR 1537).

Acknowledgments: GREiA is certified agent TECNIO in the category of technology developers from the Government of Catalonia. The authors would like to thank TER HELL \& Co. GmbH company for providing free samples of their PCM, THP5860, and to PLUSS for providing free samples of their PCM, savE OM 03.

Conflicts of Interest: The authors declare no conflicts of interest. The funders had no role in the design of the study; in the collection, analyses, or interpretation of data; in the writing of the manuscript, or in the decision to publish the results.

\section{References}

1. Dincer, I.; Rosen, M.A. Thermal Energy Storage: Systems and Applications; John Wiley and Sons: Chichester, West Sussex, UK, 2002; ISBN 978-0471495734.

2. European Commission. European Commission Communication from the Commission to the European Parliament, the Council, the European Economic and Social Committee and the Committee of the Regions and the European Investment Bank; European Commission: Brussels, Belgium, 2016.

3. Oró, E.; de Gracia, A.; Castell, A.; Farid, M.M.; Cabeza, L.F. Review on phase change materials (PCMs) for cold thermal energy storage applications. Appl. Energy 2012, 99, 513-533. [CrossRef]

4. Veerakumar, C.; Sreekumar, A. Phase change material based cold thermal energy storage: Materials, techniques and applications-A review. Int. J. Refrig. 2016, 67, 271-289. [CrossRef]

5. Cabeza, L.F.; Castell, A.; Barreneche, C.; De Gracia, A.; Fernández, A.I. Materials used as PCM in thermal energy storage in buildings: A review. Renew. Sustain. Energy Rev. 2011, 15, 1675-1695. [CrossRef]

6. Zhang, Y.; Zhou, G.; Lin, K.; Zhang, Q.; Di, H. Application of latent heat thermal energy storage in buildings: State-of-the-art and outlook. Build. Environ. 2007, 42, 2197-2209. [CrossRef]

7. Sharif, M.K.A.; Al-Abidi, A.A.; Mat, S.; Sopian, K.; Ruslan, M.H.; Sulaiman, M.Y.; Rosli, M.A.M. Review of the application of phase change material for heating and domestic hot water systems. Renew. Sustain. Energy Rev. 2015, 42, 557-568. [CrossRef]

8. de Gracia, A.; Oró, E.; Farid, M.M.; Cabeza, L.F. Thermal analysis of including phase change material in a domestic hot water cylinder. Appl. Therm. Eng. 2011, 31, 3938-3945. [CrossRef]

9. Mazman, M.; Cabeza, L.F.; Mehling, H.; Nogues, M.; Evliya, H.; Paksoy, H.Ö. Utilization of phase change materials in solar domestic hot water systems. Renew. Energy 2009, 34, 1639-1643. [CrossRef]

10. Xu, B.; Li, P.; Chan, C. Application of phase change materials for thermal energy storage in concentrated solar thermal power plants: A review to recent developments. Appl. Energy 2015, 160, 286-307. [CrossRef]

11. Prieto, C.; Cabeza, L.F. Thermal energy storage (TES) with phase change materials (PCM) in solar power plants (CSP). Concept and plant performance. Appl. Energy 2019, 254, 113646. [CrossRef] 
12. Zalba, B.; Marín, J.M.; Cabeza, L.F.; Mehling, H. Review on thermal energy storage with phase change: Materials, heat transfer analysis and applications. Appl. Therm. Eng. 2003, 23, 251-283. [CrossRef]

13. Farid, M.M.; Khudhair, A.M.; Razack, S.A.K.; Al-Hallaj, S. A review on phase change energy storage: Materials and applications. Energy Convers. Manag. 2004, 45, 1597-1615. [CrossRef]

14. Mehling, H.; Cabeza, L.F. Heat and Cold Storage with PCM. An up to Date Introduction into Basics and Applications, 1st ed.; Springer: Berlin/Heidelberg, Germany, 2008; ISBN 978-3-540-68556-2.

15. Miró, L.; Barreneche, C.; Ferrer, G.; Solé, A.; Martorell, I.; Cabeza, L.F. Health hazard, cycling and thermal stability as key parameters when selecting a suitable phase change material (PCM). Thermochim. Acta 2016, 627-629, 39-47. [CrossRef]

16. Gasia, J.; Martin, M.; Solé, A.; Barreneche, C.; Cabeza, L.F. Phase Change Material Selection for Thermal Processes Working under Partial Load Operating Conditions in the Temperature Range between 120 and $200{ }^{\circ}$ C. Appl. Sci. 2017, 7, 722. [CrossRef]

17. HYBUILD. Available online: http://www.hybuild.eu/ (accessed on 4 February 2020).

18. Frazzica, A.; Palomba, V.; Sergi, F.; Ferraro, M.; Cabeza, L.F.; Zsembinszki, G.; Oró, E.; Karellas, S.; Varvagiannis, S.; Emhofer, J.; et al. Dynamic Modelling of a Hybrid Solar Thermal/electric Energy Storage System for Application in Residential Buildings. In Proceedings of the ISES EuroSun 2018 Conference-12th International Conference on Solar Energy for Buildings and Industry, Rapperswil, Switzerland, 10-13 September 2018; p. 12.

19. Rubitherm RT-PCM. Available online: https://www.rubitherm.eu/en/index.php/productcategory/organischepcm-rt (accessed on 2 October 2019).

20. PCM Products. Available online: http://www.pcmproducts.net/ (accessed on 15 January 2019).

21. PCES Phase Change Energy Solutions. Available online: https://phasechange.com/ (accessed on 15 January 2019).

22. RGEES LLC. Available online: http://www.rgees.com/products.php (accessed on 15 January 2019).

23. PLUSS ${ }^{\circledR}$. Available online: http://pluss.co.in/ (accessed on 15 January 2019).

24. Shengli, T.; Dong, Z.; Deyan, X. Experimental study of caprylic acid/lauric acid molecular alloys used as low-temperature phase change materials in energy storage. Energy Conserv. 2005, 6, 45-47.

25. PureTemp LLC. Available online: http://www.puretemp.com/ (accessed on 15 January 2019).

26. Jankowski, N.R.; McCluskey, F.P. A review of phase change materials for vehicle component thermal buffering. Appl. Energy 2014, 113, 1525-1561. [CrossRef]

27. Pereira da Cunha, J.; Eames, P. Thermal energy storage for low and medium temperature applications using phase change materials-A review. Appl. Energy 2016, 177, 227-238. [CrossRef]

28. Pielichowska, K.; Pielichowski, K. Phase change materials for thermal energy storage. Prog. Mater. Sci. 2014, 65, 67-123. [CrossRef]

29. Climator. Available online: http://climatoribiza.com/ (accessed on 15 January 2019).

30. Kenisarin, M.; Mahkamov, K. Salt hydrates as latent heat storage materials: Thermophysical properties and costs. Sol. Energy Mater. Sol. Cells 2016, 145, 255-286. [CrossRef]

31. Sharma, A.; Tyagi, V.V.; Chen, C.R.; Buddhi, D. Review on thermal energy storage with phase change materials and applications. Renew. Sustain. Energy Rev. 2009, 13, 318-345. [CrossRef]

32. TER HELL \& Co. GmbH. Available online: https://www.terchemicals.com (accessed on 13 January 2020).

(C) 2020 by the authors. Licensee MDPI, Basel, Switzerland. This article is an open access article distributed under the terms and conditions of the Creative Commons Attribution (CC BY) license (http://creativecommons.org/licenses/by/4.0/). 